\title{
An Iron Disilyl Complex as an Effective Catalyst for the Hydrogenation of Unfunctionalized Multi-Substituted
}

\section{Alkenes}

\author{
Yoshinao Kobayash ${ }^{a}$ and Yusuke Sunada*,a,b
}

aDepartment of Applied Chemistry, School of Engineering Science, The University of Tokyo, 4-6-1

Komaba, Meguro-ku, Tokyo 153-8505, Japan.

'Institute of Industrial Science, The University of Tokyo, 4-6-1 Komaba, Meguro-ku, Tokyo 1538505, Japan.

\section{Number of pages: 8}

Number of tables: 4

Number of Figures: 2

\section{Contents}

1. General Information

p. S2

2. General procedure for hydrogenation of alkenes

p. S2

catalyzed by $\mathrm{Fe}\left[\mathrm{Si}\left(\mathrm{SiMe}_{3}\right)_{3}\right]_{2}(\mathrm{THF})_{2}(\mathbf{1})$

p. S2

3. Hydrogenation of alkene catalyzed by in-situ generated catalyst

p. S2

4. Crabtree test.

p. $\mathrm{S} 2$

5. Isolation of the hydrogenated product.

p. S2

6. Attempted hydrogenation of alkynes catalyzed by $\mathbf{1}$.

p. S3

7. Tables S1 - S4.

p. S4 
General Information. Manipulation of air and moisture sensitive compounds was carried out under a dry nitrogen atmosphere using Schlenk tube techniques associated with a high-vacuum line or in the glove box which was filled with dry nitrogen. All solvents were purchased from Kanto Chemical Co. Inc., and was dried over activated molecular sieves. ${ }^{1} \mathrm{H}$ and ${ }^{13} \mathrm{C}$ NMR spectra were recorded on a JEOL Lambda 400 spectrometer and ECZ 600 spectrometer at ambient temperature. ${ }^{1} \mathrm{H}$ and ${ }^{13} \mathrm{C}$ NMR chemical shifts ( $\delta$ values) were given in ppm relative to the solvent signal $\left({ }^{1} \mathrm{H},{ }^{13} \mathrm{C}\right)$. IR spectra were recorded on a PerkinElmer Spectrum Two spectrometer. The starting compounds, $\mathrm{Fe}\left[\mathrm{Si}\left(\mathrm{SiMe}_{3}\right)_{3}\right]_{2}(\mathrm{THF})_{2}(\mathbf{1})^{1}$ was synthesized by the method reported in the literature. All reagents were purchased from Tokyo Chemical Industries Co., Ltd. or Sigma-Aldrich, and were used without further purification.

General procedure for hydrogenation of alkenes catalyzed by $\mathrm{Fe}\left[\mathrm{Si}\left(\mathrm{SiMe}_{3}\right)_{3}\right]_{\mathbf{2}}(\mathrm{THF})_{\mathbf{2}}$ (1). In a $20 \mathrm{~mL}$ flask, catalyst 1 ( $35 \mathrm{mg}, 0.05 \mathrm{mmol}, 5 \mathrm{~mol} \%$ for the substrate) and alkenes ( $1 \mathrm{mmol}$ ) were dissolved in toluene (1 $\mathrm{mL}$ ). The atmosphere in the flask was replaced by $1 \mathrm{~atm}$ of hydrogen. In some cases, reaction was performed under $10 \mathrm{~atm}$ of $\mathrm{H}_{2}$ in the autoclave. The resulting mixture was stirred at $80^{\circ} \mathrm{C}$ for the time indicated in Table S2 and S3. Then internal standard \{1,4-bis(trimethylsilyl)benzene (45 mg, $0.2 \mathrm{mmol}$ ) $\}$ was added, and the conversion of the substrates and the yield of the products were determined by ${ }^{1} \mathrm{H}$ NMR analysis. Detailed reaction conditions are described in Table S2 and S3.

Hydrogenation of alkene catalyzed by in-situ generated catalyst. In a $20 \mathrm{~mL}$ flask, $\mathrm{KO}^{t} \mathrm{Bu}(56 \mathrm{mg}, 0.5$ $\mathrm{mmol})$ was added to the solution of $\mathrm{Si}\left(\mathrm{SiMe}_{3}\right)_{4}(160 \mathrm{mg}, 0.5 \mathrm{mmol})$ in THF $(1 \mathrm{~mL})$. The solution was stirred at room temperature for $30 \mathrm{~min}$, then $\mathrm{FeBr}_{2}(54 \mathrm{mg}, 0.25 \mathrm{mmol})$ was added to this flask. The obtained solution was stirred at room temperature for $30 \mathrm{~min}$, toluene $(4 \mathrm{~mL})$ solution of alkene (styrene or 1-decene, $5 \mathrm{mmol}$ ) was added to this solution. The atmosphere of this flask was replaced by $1 \mathrm{~atm}$ of hydrogen. The resulting mixture was stirred at room temperature for $20 \mathrm{~h}$. The yield of the formed alkane was determined by ${ }^{1} \mathrm{H}$ NMR analysis in comparison with internal standard \{1,4-bis(trimethylsilyl)benzene (45 mg, $0.2 \mathrm{mmol})\}$.

Crabtree test. In a $50 \mathrm{~mL}$ flask, catalyst 1 (35 mg, $0.05 \mathrm{mmol}, 5 \mathrm{~mol} \%$ for styrene) and styrene (104 mg, 1 $\mathrm{mmol})$ were dissolved in toluene $(0.9 \mathrm{~mL})$. The atmosphere in the flask was replaced by $1 \mathrm{~atm}$ of hydrogen. The solution was stirred for 5 minutes at room temperature. Then a solution of dibenzo[a,e]cyclooctene (10 $\mathrm{mg}, 0.05 \mathrm{mmol})$ in toluene $(0.1 \mathrm{~mL})$ was added. The atmosphere in the flask was replaced by $1 \mathrm{~atm}$ of nitrogen. The resulting mixture was stirred for $2 \mathrm{~h}$ at room temperature. Then the atmosphere in the flask was replaced by $1 \mathrm{~atm}$ of hydrogen. The resulting mixture was stirred at room temperature for 20 hours. The conversion of the styrene and the yield of the product, ethylbenzene, were determined by ${ }^{1} \mathrm{H}$ NMR analysis in comparison with internal standard $\{1,4$-bis(trimethylsilyl)benzene $(45 \mathrm{mg}, 0.2 \mathrm{mmol})\}$. The yield of the product was estimated to be $8 \%$ by the ${ }^{1} \mathrm{H}$ NMR spectrum.

Isolation of the hydrogenated product. In the hydrogenation of cis-stilbene, the hydrogenated product was isolated according to the following procedure. In a $20 \mathrm{~mL}$ flask, catalyst 1 ( $35 \mathrm{mg}, 0.05 \mathrm{mmol}, 5 \mathrm{~mol} \%$ for the substrate) and cis-stilbene $(180 \mathrm{mg}, 1 \mathrm{mmol})$ were dissolved in toluene $(1 \mathrm{~mL})$. The atmosphere in the flask was replaced by $1 \mathrm{~atm}$ of hydrogen. The resulting mixture was stirred at $80^{\circ} \mathrm{C}$ for $1 \mathrm{~h}$. Then the solvent was 
removed under reduced pressure, and the corresponding alkane, dibenzyl, was isolated by passing through the $\mathrm{Al}_{2} \mathrm{O}_{3}$ column. Isolated yield: $173 \mathrm{mg}(95 \%) .{ }^{1} \mathrm{H} \mathrm{NMR}\left(600 \mathrm{MHz}, \mathrm{CDCl}_{3}\right)$ ) 2.92 (s, 4H, $\left.\mathrm{Ar}_{-} \mathrm{CH}_{2}-\right)$, 7.18-7.19 (m, 6H, Ar-H), 7.27-7.29 (m, 4H, Ar-H). $\left.{ }^{13} \mathrm{C} \mathrm{NMR} \mathrm{(150MHz,} \mathrm{CDCl}_{3}\right) \delta: 38.10,126.05,128.47,128.58,141.92$. The actual ${ }^{1} \mathrm{H}$ and ${ }^{13} \mathrm{C}$ NMR charts were shown in Figure S1.

Attempted hydrogenation of alkynes catalyzed by 1 . In a $20 \mathrm{~mL}$ flask, catalyst 1 (35 mg, $0.05 \mathrm{mmol}, 5$ $\mathrm{mol} \%$ for the substrate) and phenylacetylene or diphenylacetylene $(1 \mathrm{mmol})$ were dissolved in toluene $(1 \mathrm{~mL})$. The atmosphere in the flask was replaced by $1 \mathrm{~atm}$ of hydrogen. The resulting mixture was stirred at $80{ }^{\circ} \mathrm{C}$ for $20 \mathrm{~h}$. Then internal standard $\{1,4$-bis(trimethylsilyl)benzene (45 $\mathrm{mg}, 0.2 \mathrm{mmol}$ ) $\}$ was added, and the conversion of the substrates and the yield of the products were determined by ${ }^{1} \mathrm{H}$ NMR analysis and GC-MS. In these reactions, quantitative formation of benzene derivatives via trimerization of alkynes were confirmed.

Monitoring the hydrogenation reaction by ${ }^{1} \mathbf{H}$ NMR spectroscopy. In a J-young NMR tube, catalyst 1 (1.6 $\mathrm{mg}, 2.0 \mu \mathrm{mol}, 5 \mathrm{~mol} \%)$ and 1-decene $(7.1 \mathrm{mg}, 40 \mu \mathrm{mol})$ were dissolved in $\mathrm{C}_{6} \mathrm{D}_{6}(0.7 \mathrm{~mL})$. The atmosphere in the NMR tube was replaced by $1 \mathrm{~atm}$ of hydrogen. The resulting mixture was kept at $80{ }^{\circ} \mathrm{C}$ for $1 \mathrm{~h}$, then ${ }^{1} \mathrm{H}$ NMR measurement was performed to detect the product.

\section{Reference}

1) Arata, S; Sunada, Y. An isolable iron(II) bis(supersilyl) complex as an effective catalyst for reduction reactions. Dalton Trans. 2019, 48, 2891-2895. 
Table S1. Hydrogenation of trans- $\alpha$-methyl-stilbene catalyzed by $\mathrm{Fe}\left[\mathrm{Si}\left(\mathrm{SiMe}_{3}\right)_{3}\right]_{2}(\mathrm{THF})_{2}$ (1) in various solvents. ${ }^{\mathrm{a}}$

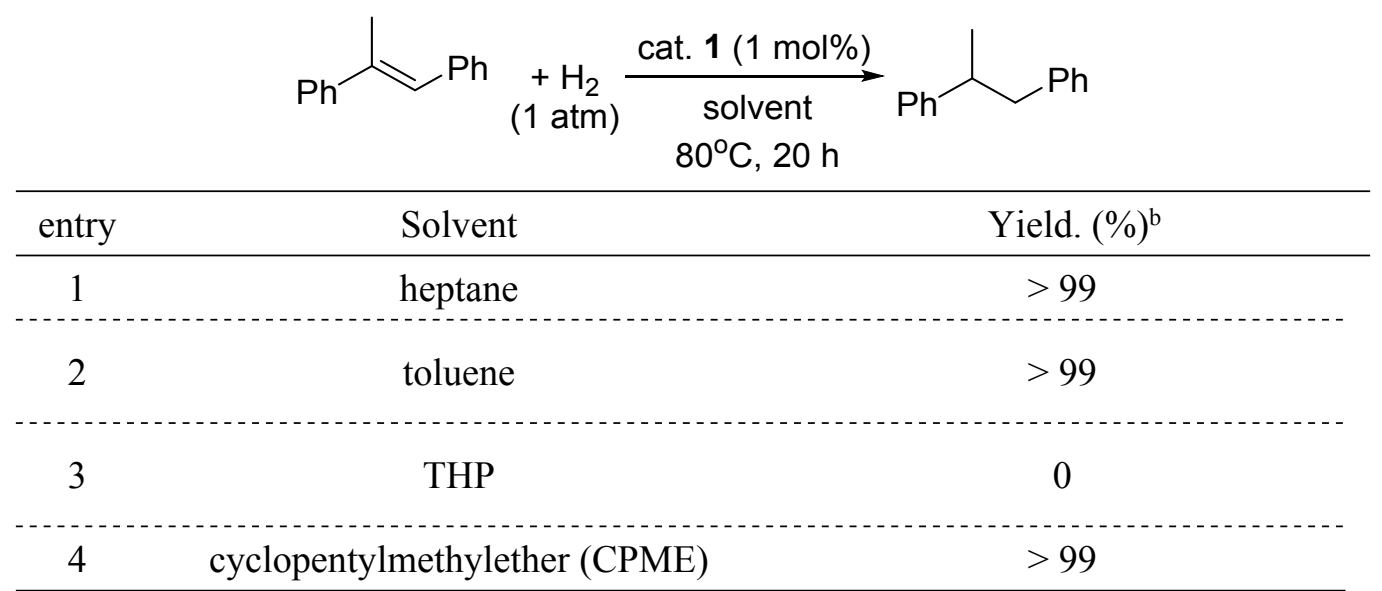

${ }^{a} \mathrm{All}$ reactions were carried out using $1 \mathrm{mmol}$ of trans- $\alpha$-methyl-stilbene under $1 \mathrm{~atm}$ of $\mathrm{H}_{2}$ in the presence of $1 \mathrm{~mol} \%$ of iron catalyst 1 in various solvent shown in this table $(1 \mathrm{~mL})$ at $80{ }^{\circ} \mathrm{C}$. ${ }^{b}$ Yield of the product was determined by ${ }^{1} \mathrm{H}$ NMR spectrum in the presence of an internal standard (1,4-bis(trimethylsilyl)benzene). 
Table S2. Hydrogenation of mono-substituted alkenes catalyzed by $\mathrm{Fe}\left[\mathrm{Si}\left(\mathrm{SiMe}_{3}\right)_{3}\right]_{2}(\mathrm{THF})_{2}(\mathbf{1}){ }^{\mathrm{a}}$

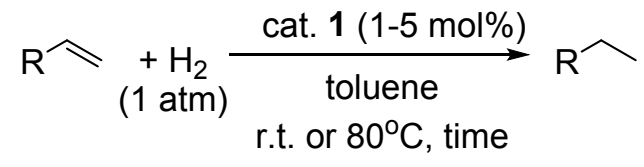

\begin{tabular}{|c|c|c|c|c|c|}
\hline entry & $\begin{array}{c}\text { cat. loading } \\
(\mathrm{mol} \%)\end{array}$ & $\begin{array}{l}\text { temp } \\
\left({ }^{\circ} \mathrm{C}\right)\end{array}$ & time (h) & alkene & yield $(\%)^{b}$ \\
\hline 1 & 5 & r.t. & 20 & $\mathrm{Ph}^{-}$ & 80 \\
\hline 2 & 5 & 80 & 1 & 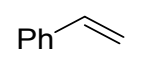 & $>99$ \\
\hline 3 & 5 & r.t. & 20 & & $>99$ \\
\hline 4 & 5 & 80 & 1 & & $>99$ \\
\hline 5 & 5 & 80 & 1 & & 65 \\
\hline 6 & 5 & 80 & 20 & & $>99$ \\
\hline 7 & 5 & 80 & 18 & & $>99$ \\
\hline 8 & 5 & 80 & 1 & & $>99$ \\
\hline 9 & 5 & 80 & 20 & & 0 \\
\hline 10 & 5 & 80 & 20 & & 0 \\
\hline $11^{\mathrm{c}}$ & 5 & r.t & 20 & & n. d $^{d}$ \\
\hline $12^{\mathrm{c}}$ & 5 & r.t & 20 & & $\mathrm{n} . \mathrm{d}^{\mathrm{d}}$ \\
\hline $13^{c}$ & 5 & r.t. & 20 & & n. d $^{d}$ \\
\hline $14^{\mathrm{c}}$ & 5 & r.t. & 20 & & n. $\mathrm{d}^{\mathrm{d}}$ \\
\hline
\end{tabular}

aAll reactions were carried out using $1 \mathrm{mmol}$ of the alkene in the presence of a $5 \mathrm{~mol} \%$ of iron catalyst $\mathbf{1}$ in toluene $(1 \mathrm{~mL})$. ${ }^{b}$ Yield of the product was determined by ${ }^{1} \mathrm{H}$ NMR spectrum in the presence of an internal standard (1,4-bis(trimethylsilyl)benzene). 'No hydrogenation of alkene proceeded even at $80^{\circ} \mathrm{C}$, instead, polymerization of alkene took place predominantly. ${ }^{\text {d‘ }}$ n.d." indicates "not detected". 
Table S3. Hydrogenation of various alkenes catalyzed by $\mathrm{Fe}\left[\mathrm{Si}\left(\mathrm{SiMe}_{3}\right)_{3}\right]_{2}(\mathrm{THF})_{2}(\mathbf{1}){ }^{\mathrm{a}}$

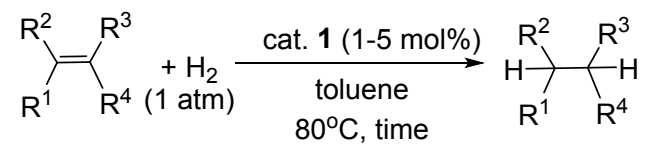

\begin{tabular}{|c|c|c|c|c|c|}
\hline entry & $\begin{array}{c}\text { cat. loading } \\
(\mathrm{mol} \%)\end{array}$ & $\begin{array}{l}\text { temp } \\
\left({ }^{\circ} \mathrm{C}\right)\end{array}$ & time $(\mathrm{h})$ & alkene & yield $(\%)^{b}$ \\
\hline 1 & 5 & 80 & 2 & & $>99$ \\
\hline 2 & 5 & 80 & 1 & & $>99$ \\
\hline 3 & 5 & 80 & 2 & & $>99$ \\
\hline 4 & 5 & 80 & 20 & & n.d \\
\hline 5 & 5 & 80 & 2 & & 30 \\
\hline 6 & 5 & 80 & 20 & & $>99$ \\
\hline 7 & 5 & 80 & 2 & & $>99$ \\
\hline 8 & 5 & 80 & 2 & & $>99$ \\
\hline 9 & 1 & 80 & 2 & & $>99$ \\
\hline 10 & 5 & 80 & 20 & & $>99$ \\
\hline 11 & 5 & 80 & 20 & & n. $\mathrm{d}^{\mathrm{d}}$ \\
\hline 12 & 5 & 80 & 20 & & n. d $^{d}$ \\
\hline 13 & 5 & 80 & 20 & & 19 \\
\hline $14^{c}$ & 5 & 80 & 20 & & 50 \\
\hline 15 & 5 & 80 & 20 & & n. $\mathrm{d}^{\mathrm{d}}$ \\
\hline 16 & 5 & 80 & 20 & & n. d $^{d}$ \\
\hline
\end{tabular}

${ }^{a}$ All reactions were carried out using $1 \mathrm{mmol}$ of the alkene in the presence of a catalytic amount of the iron catalyst in toluene $(1 \mathrm{~mL}) .{ }^{\text {b}}$ Yield of the product was determined by ${ }^{1} \mathrm{H}$ NMR spectrum in the presence of an internal standard (1,4-bis(trimethylsilyl)benzene). "Reaction was performed under 10 atm of $\mathrm{H}_{2}$. ${ }^{\text {acn.d." }}$ indicates "not detected". 
Table S4. Hydrogenation of styrene or 1-decene catalyzed by in situ generated iron catalyst or various catalyst precursors. $^{\mathrm{a}}$

\begin{tabular}{|c|c|c|c|}
\hline entry & alkene & cat. & yield $(\%)^{b}$ \\
\hline 1 & styrene & $\begin{array}{c}\mathrm{FeBr}_{2}(5 \mathrm{~mol} \%)+\text { 2equiv. } \mathrm{KO}^{t} \mathrm{Bu} \\
+ \text { 2equiv. } \mathrm{Si}\left(\mathrm{SiMe}_{3}\right)_{4}\end{array}$ & $>99$ \\
\hline 2 & styrene & $\mathrm{FeBr}_{2}(5 \mathrm{~mol} \%)$ & n.d d $^{\mathrm{c}}$ \\
\hline 3 & styrene & $\mathrm{KO}^{t} \mathrm{Bu}(10 \mathrm{~mol} \%)+\mathrm{Si}\left(\mathrm{SiMe}_{3}\right)_{4}$ & n.d $d^{c, d}$ \\
\hline 4 & 1-decene & $\begin{array}{c}\mathrm{FeBr}_{2}(5 \mathrm{~mol} \%)+2 \text { equiv. } \mathrm{KO}^{\prime} \mathrm{Bu} \\
+ \text { 2equiv. } \mathrm{Si}\left(\mathrm{SiMe}_{3}\right)_{4}\end{array}$ & $>99$ \\
\hline
\end{tabular}

${ }^{a}$ All reactions were carried out using $5 \mathrm{mmol}$ of alkene under $1 \mathrm{~atm}$ of $\mathrm{H}_{2}$ in the presence of 5 or $10 \mathrm{~mol} \%$ of the catalyst precursor in toluene/THF ( $4 \mathrm{~mL}$ of toluene and $1 \mathrm{~mL}$ of THF) at $80^{\circ} \mathrm{C}$. b Yield of the product was determined by ${ }^{1} \mathrm{H}$ NMR spectrum in the presence of an internal standard (1,4-bis(trimethylsilyl)benzene). c"n.d." indicates "not detected". "styrene was completely converted to polystyrene due to the rapid polymerization. 
Figure S1. ${ }^{1} \mathrm{H}$ NMR spectrum of dibenzyl in $\mathrm{CDCl}_{3}$ at room temperature.

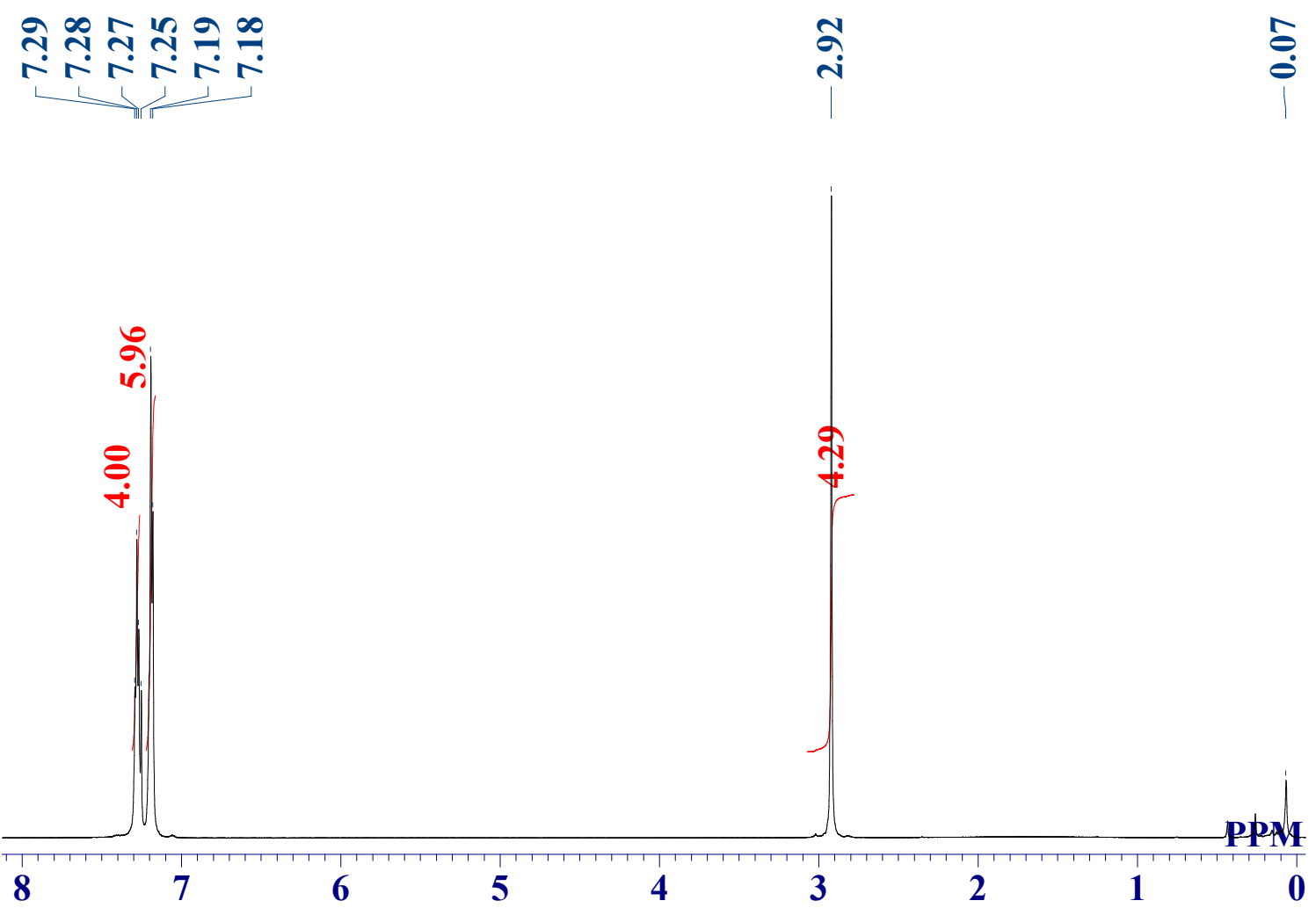

Figure S2. ${ }^{13} \mathrm{C}$ spectrum of dibenzyl in $\mathrm{CDCl}_{3}$ at room temperature.

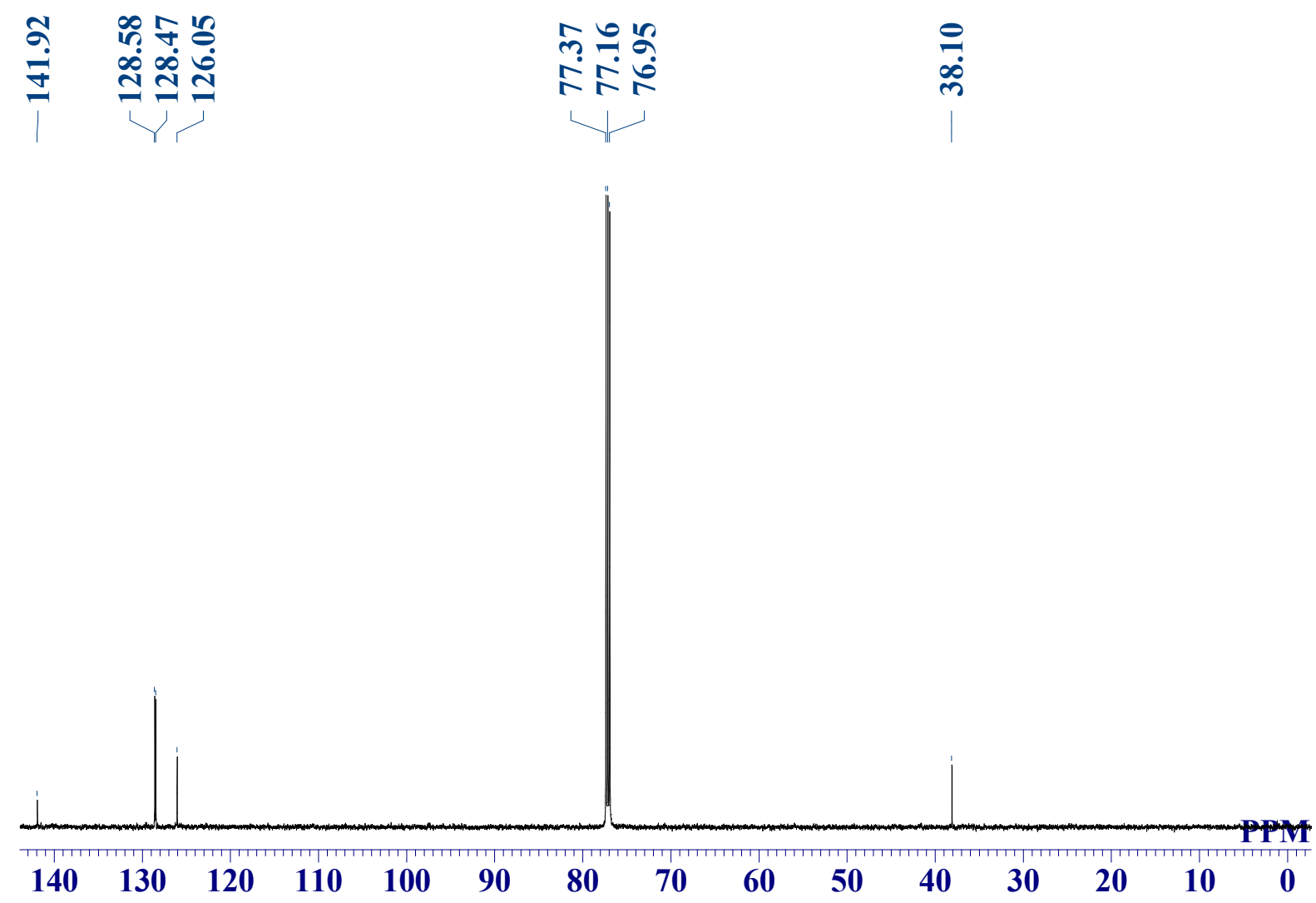

